\title{
Association of new obesity indices: visceral adiposity index and body adiposity index, with metabolic syndrome parameters in obese patients with or without type 2 diabetes mellitus
}

\author{
Mahmood Dhahir Al-Mendalawi(D)
}

To the Editor,

I read with interest the study by Rashad and Emad [1] published in the October to December 2019 issue of The Egyptian Journal of Internal Medicine. On using International Diabetes Federation (IDF) definition for metabolic syndrome (MetS), Rashad and Emad [1] assessed the association of the new obesity indices, visceral adiposity index (VAI) and body adiposity index (BAI), with the parameters of MetS in a cohort of Egyptian obese patients. They found that BAI and VAI and MetS parameters (triglycerides and high-density lipoprotein cholesterol) might reflect indirectly other non-classical risk factors correlated with the occurrence of obesityrelated co-morbidities [1]. I presume that such findings ought to be cautiously exercised. This is based on the presence of the following methodological limitation related to the tool employed in the diagnosis of MetS. The role of this limitation could be addressed in two aspects. On one hand, it is obvious that there are many MetS definitions, namely National Cholesterol Education Program Adult Treatment Panel III (NCEP-ATP III), IDF, American Heart Association (AHA), Joint Interim Statement (JIS), and World Health Organization (WHO). Importantly, there is an inconsistent consensus on the accuracy of different definitions to diagnose MetS [2, 3]. Estimating the MetS prevalence in adult Egyptian population employing various definitions interestingly disclosed different results, notably 43.8\% (AHA definition),

Correspondence: mdalmendalawi@yahoo.com

Department of Paediatrics, Al-Kindy College of Medicine, University of Baghdad, P.O. Box 55302, Post Office, Baghdad, Baghdad, Iraq
42.5\% (NCEP-ATP III definition), 44.3\% (IDF definition), 33.8\% (IDF definition with Egyptian cutoffs), and 41.5\% (JIS definition with Egyptian cutoffs) [4]. On the other hand, the IDF definition employed in the study by Rashad and Emad [1] is old dated back to 2005 and consists of European cutoffs for MetS parameters [5] making it inconvenient to be utilized in clinical practice and research purposes for Egyptian population. It has been recommended that the JIS definition with an Egyptian cutoff represents the most suitable tool for defining MetS in Egyptians [4]. Thus, its utilization instead of IDF definition in the study methodology by Rashad and Emad [1] could make the study results more accurate.

\section{Abbreviations}

IDF: International Diabetes Federation; MetS: Metabolic syndrome; VAl: Visceral adiposity index; BAl: Body adiposity index; NCEP-ATP III: National Cholesterol Education Program Adult Treatment Panel III; AHA: American Heart Association; JIS: Joint Interim Statement; WHO: World Health Organization

\section{Acknowledgements}

Not applicable

\section{Author's contributions}

Concept, design, literature review, preparation and editing of the manuscript, reading, and approving the final manuscript

\section{Funding}

None

\section{Availability of data and materials} Not applicable

\section{Ethics approval and consent to participate} Not applicable

\section{Springer Open}

(๑) The Author(s). 2020 Open Access This article is licensed under a Creative Commons Attribution 4.0 International License, which permits use, sharing, adaptation, distribution and reproduction in any medium or format, as long as you give appropriate credit to the original author(s) and the source, provide a link to the Creative Commons licence, and indicate if changes were made. The images or other third party material in this article are included in the article's Creative Commons licence, unless indicated otherwise in a credit line to the material. If material is not included in the article's Creative Commons licence and your intended use is not permitted by statutory regulation or exceeds the permitted use, you will need to obtain permission directly from the copyright holder. To view a copy of this licence, visit http://creativecommons.org/licenses/by/4.0/. 


\section{Consent for publication}

Not applicable

\section{Competing interests \\ None}

Received: 2 September 2020 Accepted: 16 December 2020

Published online: 15 January 2021

\section{References}

1. Rashad NM, Emad G (2019) Association of new obesity indices; visceral adiposity index and body adiposity index, with metabolic syndrome parameters in obese patients with or without type 2 diabetes mellitus. Egypt J Intern Med 31(4):620-628

2. Ebrahimi H, Emamian MH, Khosravi A, Hashemi H, Fotouhi A (2019)

Comparison of the accuracy of three diagnostic criteria and estimating the prevalence of metabolic syndrome: a latent class analysis. J Res Med Sci 24: 108. https://doi.org/10.4103/jrms.JRMS_858_18

3. do Vale Moreira NC, Hussain A, Bhowmik B, Mdala I, Siddiquee T, Fernandes VO et al (2020) Prevalence of metabolic syndrome by different definitions, and its association with type 2 diabetes, pre-diabetes, and cardiovascular disease risk in Brazil. Diabetes Metab Syndr 14(5):1217-1224. https://doi.org/ 10.1016/j.dsx.2020.05.043

4. Assaad-Khalil SH, Mikhail MM, Aati TA, Zaki A, Helmy MA, Megallaa MH et al (2015) Optimal waist circumference cutoff points for the determination of abdominal obesity and detection of cardiovascular risk factors among adult Egyptian population. Indian J Endocrinol Metab 19(6):804-810. https://doi. org/10.4103/2230-8210.167556

5. Alberti KGM, Zimmet P, Shaw J, Group I, IDF Epidemiology Task Force Consensus Group (2005) The metabolic syndrome -a new worldwide definition. Lancet 366(9491):1059-1062. https://doi.org/10.1016/S01406736(05)67402-8

\section{Publisher's Note}

Springer Nature remains neutral with regard to jurisdictional claims in published maps and institutional affiliations.

\section{Submit your manuscript to a SpringerOpen ${ }^{\circ}$ journal and benefit from:}

- Convenient online submission

- Rigorous peer review

- Open access: articles freely available online

- High visibility within the field

- Retaining the copyright to your article 